\title{
Using Communication Strategies to Operationalise United Nations Security Council Resolution 1325
}

\author{
Author: Bibby, Claire
}

To cite this article: Bibby, C. (2021). Using Communication Strategies to Operationalise United Nations Security Council Resolution 1325. National Security Journal, 3(1). doi:10.36878/nsj20210405.01

To link to this article: https://doi.org/10.36878/nsj20210405.01

View CrossRef data: https://search.crossref.org/?q=10.36878\%2Fnsj20210405.01 


\title{
USING COMMUNICATION STRATEGIES TO OPERATIONALISE UNITED NATIONS SECURITY COUNCIL RESOLUTION 1325 WOMEN, PEACE AND SECURITY
}

\author{
Claire Bibby ${ }^{1}$
}

\begin{abstract}
United Nations Security Council resolution 1325 Women, Peace and Security was adopted by the United Nations Security Council in 2000 and is founded on the principle of building and maintaining sustainable peace and security. Importance is placed on communication with women to implement the resolution and the role of women as leaders, not victims, in the peace and security discussion. This study researches the New Zealand Police approach to implementing resolution 1325 in the Asia-Pacific region. It examines the role of police communication in enabling the voice of women to be heard in decision making to prevent conflict, conflict resolution and in post conflict situations. In doing so, it highlights barriers and opportunities for NZ Police personnel communicating with people of a different gender to their own. This research provides evidence of the value of studying NZ Police communication approaches to inform an evidence-based communication strategy that benefits the agency and its personnel implementing the resolution.
\end{abstract}

Keywords: New Zealand Police, International Security, Peacekeeping, Asia-Pacific, Gender, Communication, Image, Visual Representation, Language, Culture and Religion, United Nations Security Council Resolution 1325.

\section{Introduction}

United Nations Security Council (UNSC) resolution 1325 Women, Peace and Security is founded on the principle of building and maintaining sustainable peace and security. ${ }^{1} \mathrm{UN}$ member states are urged to seek wider representation and decision-making of women for the prevention and resolution of conflict. ${ }^{2}$

$1 \quad$ Claire Bibby is a graduate of the Master of International Security programme at the Centre for Defence and Security Studies at Massey University. This article is abridged from a research project, for which Claire received the 2018 Australasian Council of Women and Policing Award for Excellence in Research to Improve Law Enforcement for Women. The supervision of Dr Negar Partow, Massey University, is acknowledged. A New Zealand police officer for 35 years, Claire retired in 2021. Contact via E-mail: cbibby@orcon.net.nz. 
When resolution 1325 was adopted by the UNSC in 2000, it was the first time the international community recognised the experience and impact of conflict on women and the contribution women make in the decision-making process for peace and security. ${ }^{3}$ The UN also released a media statement in 2000 , outlining the importance of communication to implement the resolution and the role of women as leaders, not victims, in peace and security. ${ }^{4}$ Member states implement the resolution through National Action Plans. ${ }^{5}$ As at December 2020, 89 countries have adopted a National Action Plan in support of resolution $1325 .{ }^{6}$

The year 2015 marked New Zealand's election to the UNSC as a non-permanent member and the $15^{\text {th }}$ anniversary of the UNSC adopting resolution 1325. It was the year New Zealand introduced its National Action Plan for Women, Peace and Security to the UNSC. The Ministry for Foreign Affairs and Trade (MFAT) led the development of the plan in partnership with NZ Police, NZ Defence and the Ministry for Women. ${ }^{7}$ MFAT is the lead agency for co-ordinating annual reports to the respective Ministers on its implementation from MFAT, NZ Police, NZ Defence Force, and the Ministry for Women, and for presenting a combined report to the public, consulted with the civil sector. ${ }^{8}$

This article argues that communication strategies are crucial in achieving implementation of resolution 1325 and that relevant, gender representative imagery (visual representation) in police communication will contribute positively to operationalizing the resolution. The work brings a focus to the significant role of New Zealand policing in the Pacific. Many of the small island states in the Pacific do not have a military and reply on their police for security. This means countries like New Zealand, which provide police as mentors and trainers to police in the Pacific and other parts of the world, have an important role to play in regional and international security and that police communication, representative and inclusive of women, is critical to that role. Furthermore, the 2016 Asia-Pacific Regional Symposium on National Action Plans for Women, Peace and Security identified three emerging drivers of conflict - violent extremism, climate change and population displacement - and reinforced the need for gender-inclusive knowledge and gender responsive solutions. ${ }^{9}$ As resolution 1325 focuses on enabling women's voice to be heard in decision making, this study researches the communication approaches of NZ Police personnel toward achieving this intent.

\section{A comment on images and visual representation}

International Relations theorist Cynthia Weber contends that the study of popular images gives them a meaningful political life and helps our understanding of their influence and importance in global communication. ${ }^{10}$ It is important to select any images for publication carefully. As Cynthia Enloe points out, images are so powerful that if the image is wrong, the whole message is wrong. ${ }^{11}$ Vanya Harris and Andrew Goldsmith warn against "constructing feminine roles" for women in policing, which ensure the 
perceived image of policing as "tough and masculine". ${ }^{2}$ This study on police imagery reveals whether it is used by police to communicate working in equal partnership with women or is used to reinforce a masculine - feminine construct of policing.

\section{International Policing}

New Zealand has been continuously involved in UN peacekeeping activities since the 1950's and deployed Police to Cyprus from 1964-1967, to Namibia in 1989-1990, Timor-Leste in 1999-2001 and again in 2008-2012, as well as Afghanistan in 2009$2012 .{ }^{13}$ Today NZ Police work as mentors or advisors in post-conflict states such as Bougainville, the Solomon Islands and Timor-Leste. ${ }^{14}$ They also mentor the Fiji Detector Dog Programme, the Pacific Prevention of Domestic Violence Programme and operate a Partnership for Pacific Policing capacity development programme in Cook Islands, Kiribati, Niue, Samoa, Tokelau, Tuvalu and Vanuatu. ${ }^{15}$ NZ Police are based in Tonga with the Tonga Police Development Programme and since 2008 provide a policing service for the Pitcairn Islands. ${ }^{16}$ NZ Police liaison officers are based in Apia, Bangkok, Beijing, Canberra, Guangzhou, Jakarta, London, Sydney, Washington, and Hong Kong. ${ }^{17}$. NZ Police also deploy for short-term event policing, for example, memorial services at Gallipoli, the United Nations Small Islands Developing States conference in Samoa and the G20 summit in Brisbane. ${ }^{18}$

\section{Methodology}

This article discusses the results of a survey of New Zealand Police officers and non-constabulary employees as well as two focus groups from NZ Police National Headquarters International Services Group, which is responsible for administrating New Zealand deployments overseas. The purpose of the survey was to capture the experiences of NZ Police personnel who have held a role in international policing or may have influenced decisions relating to the NZ Police international policing response. It was anticipated that unless the survey recipient had been deployed overseas, most of respondents would not work under the line management of a District Commander. The Headquarters personnel surveyed fell into three groups. The first group were those who likely worked in an international security role, for example, intelligence, protection services (responsibilities include protecting the Governor General, Prime Minister and visiting dignitaries), special tactics (terrorism, high-risk covert surveillance, deployed overseas to assist with security operations) and international services (international emergency and crisis, mentoring, peace-support, post-conflict capacity building). ${ }^{19}$ The second group were those who make decisions about who works in these roles, such as workgroup managers, the Police Executive, District Commanders and people in Human Resources. The third group were those who influence the public and police perception of international security through media, recruitment marketing, print and online publishing, and the NZ Police Museum. 
The survey was emailed to police personnel in 2017 and was open for 14 days. Owing to institutional barriers, the survey could not be publicised and no reminder notice to participate could be sent. The survey was emailed to 509 people and 151 responded.

The survey had 23 questions. The first part of the survey asked questions about the respondent's gender, whether they were constabulary or non-constabulary staff, their rank, age bracket, length of service. Definitions for gender and gender equality in the survey were sourced from UN Women (the UN Entity for Gender Equality and the Empowerment of Women). ${ }^{20}$ Some general knowledge questions were asked about the principles of policing, the United Nations conventions relating to gender, and the NZ National Action Plan for Women, Peace and Security.

Part way through the survey, a question was designed to separate those who have policed internationally, from those who have not. Those who have policed internationally, were asked questions about communicating with people of a different gender to one's own in international fora. This included questions about barriers to communicating and what enables communication to work well. Questions were also asked about respondent's levels of safety when communicating with indigenous people, expatriates and partner agencies of a different gender to their own, in public and in private. Respondents could also comment to open ended questions.

The participants in the focus groups were volunteers from the International Services Group (ISG) within police. The ISG has the lead for implementing the police actions in the NZ National Action Plan. The focus groups were gender based, with five women in one group and four men in the other. The purpose of the focus groups was to establish what the participants understood of the NZ National Action Plan and ways it influenced their work. Questions were asked about the way ISG communicated the plan, the key players, and pathways for greater or lesser resistance to delivering it. Participants were also invited to bring an image or photograph that represents New Zealand's international policing at its best. They were asked 'What message does the image present about New Zealand policing internationally?' 'What messages are there about gender?' and 'How could imagery be used in messaging for the implementation plan?'2

\section{Survey findings}

During the two weeks the survey was open, it was undertaken by 151 personnel of whom 101 identified as male and 50 as female and none as gender diverse. Most of the respondents, a total of 111 , ( $74 \%$ males and $72 \%$ females) did not work under the line management of a District Commander, indicating the influence of Police Headquarters personnel in international policing.

2 The survey and focus group designs were subject to the Massey University Code of Ethical Conduct for Research, Teaching and Evaluations involving Human Participants and were submitted to the Massey University Ethics Committee for assessment and were approved. 
Of the 151 respondents, 100 were constabulary staff comprising 84 male and 16 female personnel. Constables have the full range of statutory and common law powers. They are trained differently to non-constabulary staff on recruitment into the Police and in this research are more likely to have worked internationally than non-constabulary staff (see Table 5). The non-constabulary staff comprised of 17 male and 34 female personnel. The percentage of female constables who responded to the survey was $32 \%$, which was statistically higher than the number of female constabulary staff working in NZ Police, at 19\% (see Table 1 and Table 2). People aged $46-55$ represented $40.4 \%$ of survey respondents, followed by those aged 36-44 (25.85\%) and those aged 56 and over (21.19\%) (see Figure 1). People with 23-32 years of policing service represented the largest service group of respondents (29.13\%).

Table 1: NZ Police personnel by gender, at 30 June $2016^{21}$

\begin{tabular}{|l|r|r|r|}
\hline Gender & \multicolumn{1}{|c|}{ Constabulary } & Other Employees & \multicolumn{1}{c|}{ Total } \\
\hline Female & 1,720 & 2,033 & 3,753 \\
\hline Male & 7,284 & 998 & 8,282 \\
\hline Total & 9,004 & 3,031 & 12,034 \\
\hline \%age female & $19.1 \%$ & $67.1 \%$ & $31.2 \%$ \\
\hline
\end{tabular}

Table 2: NZ Police survey respondents by gender

\begin{tabular}{|l|r|r|r|}
\hline Gender & Constabulary & Non-constabulary & Total \\
& & (Other employees) & \\
\hline Female & 16 & 34 & 50 \\
\hline Male & 84 & 17 & 101 \\
\hline Total & 100 & 51 & 151 \\
\hline \%age female & $32 \%$ & $68 \%$ & $33.11 \%$ \\
\hline
\end{tabular}

When asked what ethnic group or groups they identified themselves as, most respondents (112 of 151) did not identify solely as New Zealanders. They included their ethnic affiliation, for example "Maori, Euro, Chinese" or "NZ European, Scottish, Irish". They also used language that is indigenous to New Zealand, such as Maori, Kiwi and Pakeha, and two people identified their religious affiliation. 
Figure 1: Age bracket of NZ Police survey respondents.

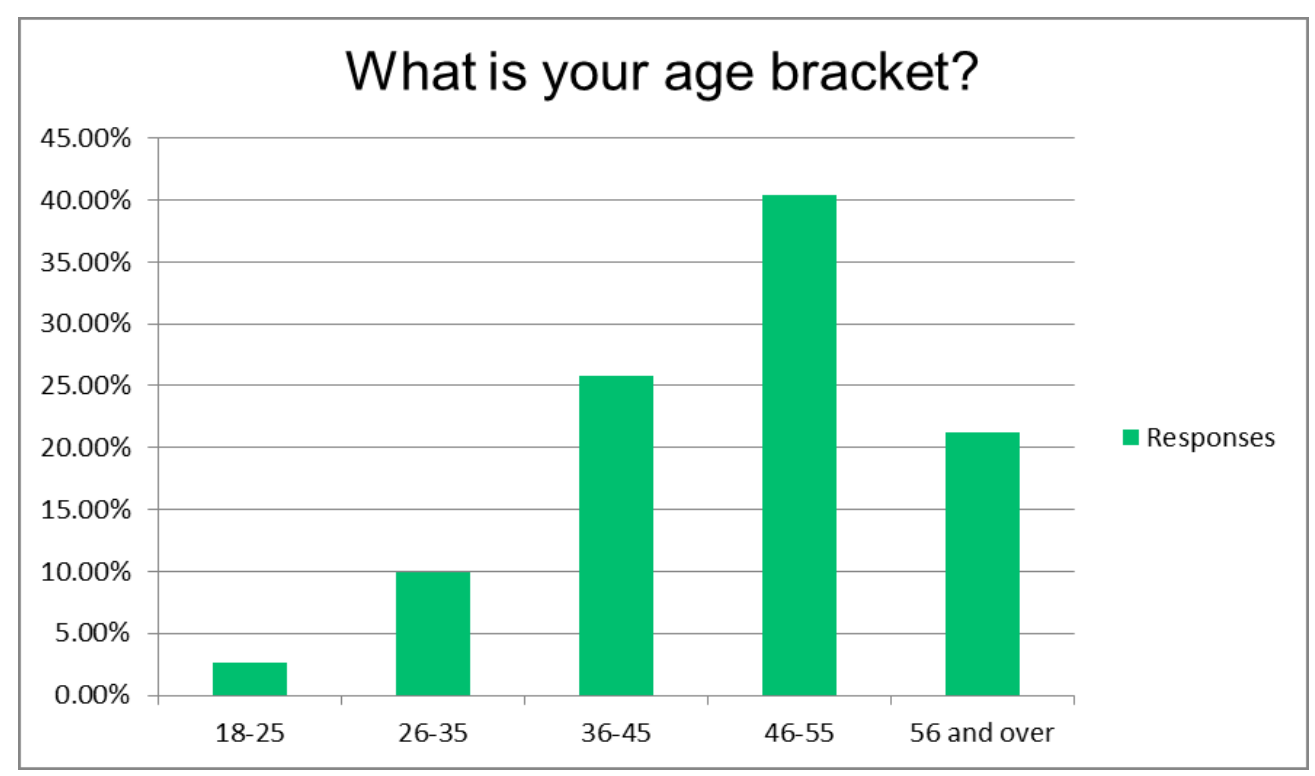

\section{Relevance of gender to policing}

The Policing Act 2008 provides for the governance and administration of the NZ Police. The Act is based on the following principles:

a. principled, effective, and efficient policing services are a cornerstone of a free and democratic society under the rule of law:

b. effective policing relies on a wide measure of public support and confidence:

c. policing services are provided under a national framework but also have a local community focus:

d. policing services are provided in a manner that respects human rights:

e. policing services are provided independently and impartially:

f. in providing policing services every Police employee is required to act professionally, ethically, and with integrity.

When asked "How relevant is gender to the principles of policing?" there was a statistically significant variance in the response to this question between males and females. Thirty-two females (68 \%) said gender is very relevant to policing and one said it is the 
main focus. This compared to 40 males (42\%) who said gender is very relevant to the principles of policing. A total 51 males $(54.26 \%)$ felt it is relevant to a limited degree or not relevant at all compared to 13 females (27.66\%).

When staff were asked about how relevant gender is in their current workplace, its relevance reduced further, revealing a gap between the theory and the reality in the workplace. For example, 27 males $(32.98 \%)$ said gender is very relevant compared to 10 females (45.65\%). However, conversely, 61 males $(64.89 \%)$ compared to 24 females $(52.17 \%)$ responded that gender is relevant to a limited degree or not relevant at all in the workplace.

These questions were looked at again, in relation to whether the respondent was a constable or not. The results showed that constables are less likely to believe gender is relevant in the workplace compared to non-constabulary staff. Thirty-two constables $(34.78 \% \%)$ thought gender is very relevant, 26 constables $(28.26 \%)$ thought gender is relevant to a limited degree and 32 constables (34.78\%) not relevant at all. This compared to $19(39.58 \%)$ of non-constabulary staff who thought gender is very relevant, $11(22.45$ $\%)$ relevant to a limited degree and $16(33.33 \%)$ not relevant at all. The data provides a benchmark for improving police understanding of the relevance of gender to policing.

Figure 2: Male and female perceptions of the relevance of gender to principles of policing

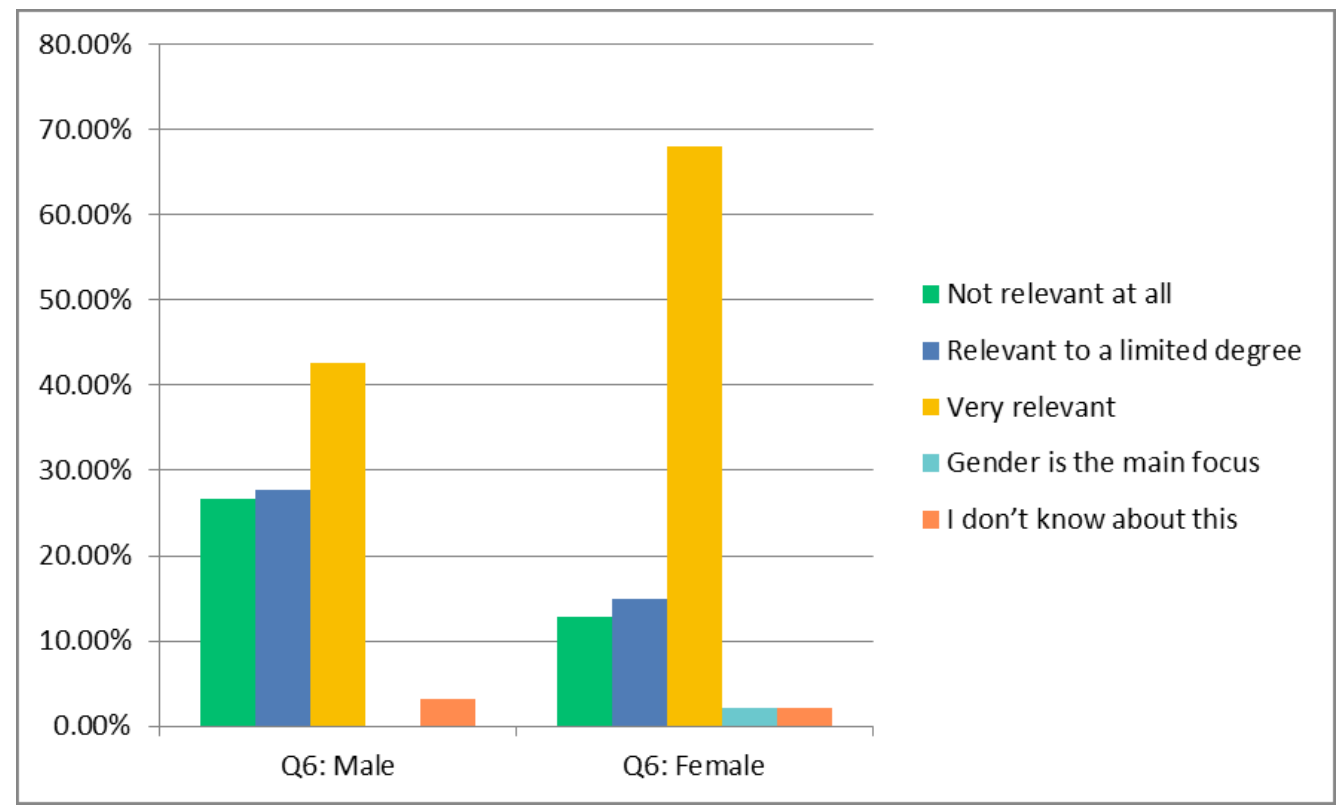


Figure 3: Constabulary and non-constabulary perceptions of the relevance of gender to principles of policing

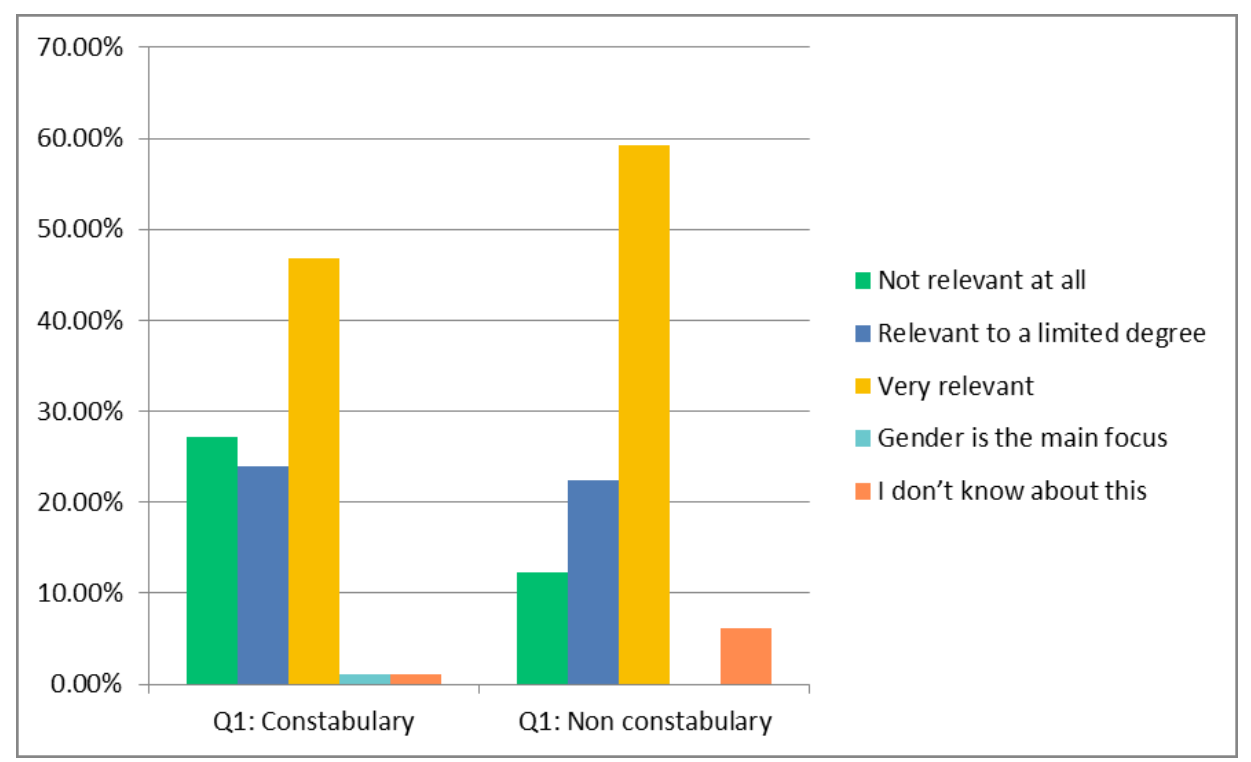

Figure 4: Male and female perceptions of the relevance of gender to the workplace

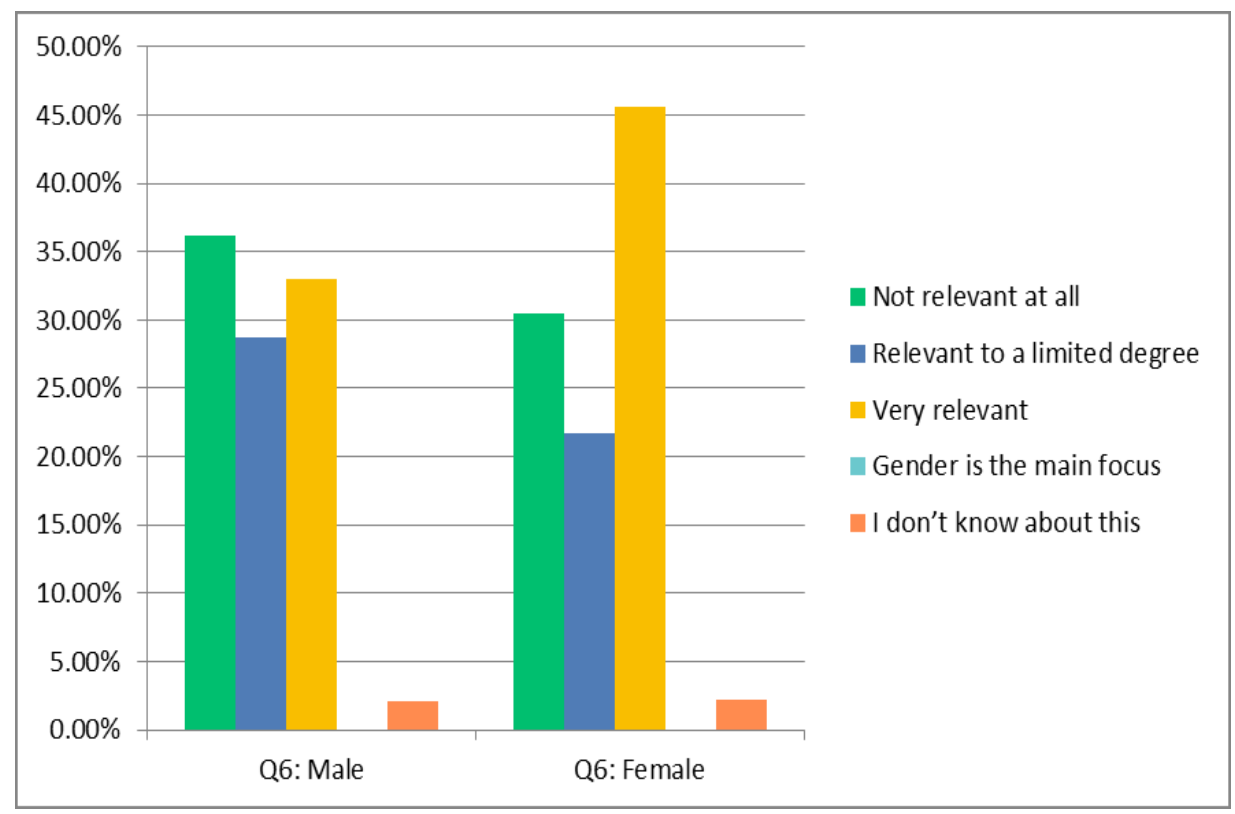


Figure 5: Constabulary and non-constabulary perceptions of the relevance of gender to the workplace

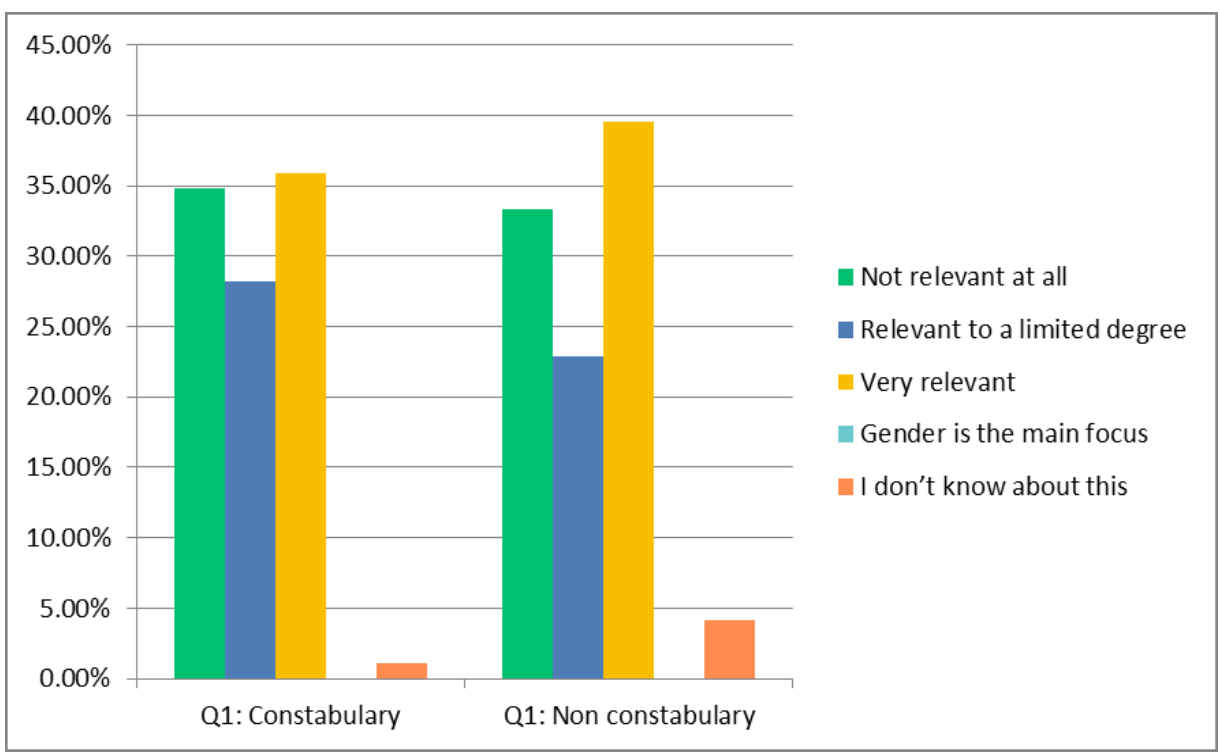

Table 3: Perceptions of how relevant gender is to the principles of policing

\begin{tabular}{|l|r|r|r|r|}
\hline Relevance & Female & Male & Const. & Non-const. \\
\hline Vey relevant & $68.09 \%$ & $42.55 \%$ & $46.74 \%$ & $59.18 \%$ \\
\hline Relevant to limited degree & $14.89 \%$ & $28.72 \%$ & $23.91 \%$ & $22.45 \$$ \\
\hline Not relevant at all & $12.77 \%$ & $26.60 \%$ & $27.17 \%$ & $12.24 \%$ \\
\hline
\end{tabular}

Table 4: Perceptions of how relevant is gender to the current workplace

\begin{tabular}{|l|c|c|r|r|}
\hline Relevance & Female & Male & \multicolumn{1}{c|}{ Const. } & Non-const. \\
\hline Vey relevant & $45.65 \%$ & $32.98 \%$ & 35.87 & $39.58 \%$ \\
\hline Relevant to limited degree & $21.74 \%$ & $28.72 \%$ & $28.26 \%$ & $22.92 \%$ \\
\hline Not relevant at all & $30.43 \%$ & $36.17 \%$ & $34.78 \%$ & $33.33 \%$ \\
\hline
\end{tabular}




\section{How well are United Nations Security Council resolutions communicated?}

New Zealand Police report on United Nations Security Council conventions and resolutions relating to gender equality through the Ministry for Women. ${ }^{22}$ These are the NZ National Action Plan for Women, Peace and Security, the Beijing Declaration, and the Convention on the Elimination of All Forms of Discrimination against Women. ${ }^{23}$ When asked about their familiarity with United Nations conventions and resolutions on gender equality, $53.19 \%$ of females and $57.89 \%$ of males (54.84 \% of constables and $59.34 \%$ of non-constabulary staff) responded that they were not at all familiar with them. Only two males and one female said they use the United Nations conventions on gender equality in their everyday work.

When asked how familiar they are with the NZ National Action Plan for United Nations Security Council resolutions, including 1325 Women, Peace and Security, 82.52\% or 118 people responded that they were not at all familiar with the NZ National Action Plan. There is little variation between male $(81.25 \%)$ and female $(85.11 \%)$ or constabulary $(81.91 \%)$ and non-constabulary $(83.67 \%)$. When asked if they had read the NZ National Action Plan, $89.51 \%$ said they had not. If the influencers and decision makers in police are better informed about the intent and value of resolution 1325, then women's contribution toward peace and security will have increased opportunity to be actualised.

\section{Opportunities for communicating internationally}

The survey identified those who had policed internationally by asking whether respondents had attended an international meeting, convention, conference or training; undertaken a short-term deployment, such as responding to an international disaster, or crowd control type events, or undertaken an in-country residential deployment.

Ninety-four of 143 respondents answering this question have policed internationally of whom 85 are constables. There is a significant statistical variation with $79.17 \%$ of all male respondents having policed internationally compared to $38.30 \%$ of all female respondents. The evidence showed that when women do police internationally, they are less likely to participate in key opportunities for communicating, networking and influencing policing (see Figure 6). Eighty-seven people responded to the question designed to identify key opportunities for communicating, networking and influential policing. Between January 2016 and July 2017, most respondents had participated in meetings $(77.01 \%)$, provided or attended training with international participants (58.62\%), and some had attended an international convention, conference, or symposium (34.38\%). However, on a percentage basis, women participate less than men and more women $(37.50 \%)$ than men $(12.68 \%)$ did not participate at all. 
By not participating in matters relating to international policing women are less visible, less likely to have their voice heard, less likely to engage with women and men on the international peace and security circuit and are excluded from opportunities to participate and contribute to the peace and security mandate.

Table 5: Survey respondents who have policed internationally.

\begin{tabular}{|r|r|r|r|}
\hline \multicolumn{1}{|c|}{ Female } & Male & Constabulary & \multicolumn{1}{|c|}{ Non-constabulary } \\
\hline 18 & 76 & 85 & 9 \\
\hline
\end{tabular}

Figure 6: Participation of male and female police personnel in international policing situations from January 2016 - July 2017

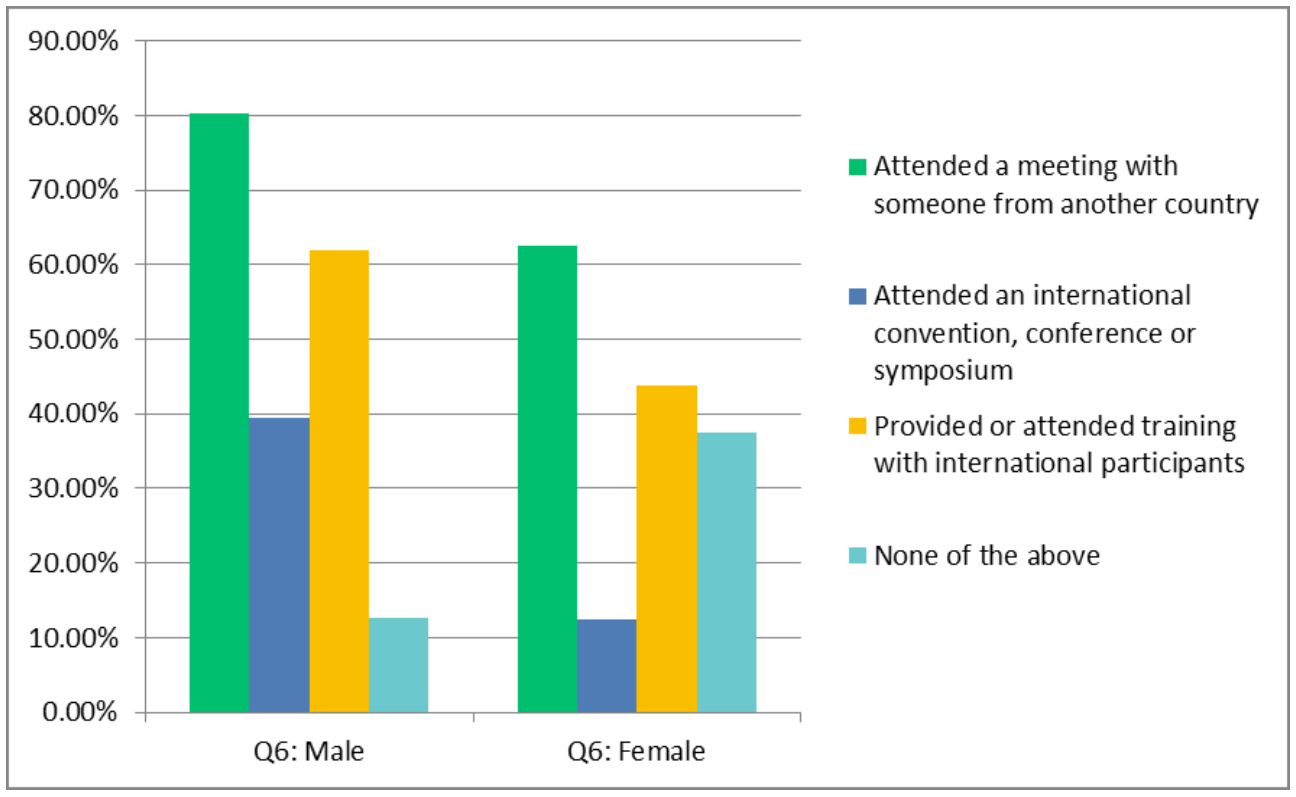

\section{Enabling good communication between genders}

Participants were asked "Thinking about your international policing experience, what best encourages or enables communication with people of a different gender to you." Sixty-four males and 15 females responded with comments and their responses are displayed in a word cloud image with most popular words graduating to larger sized font (see Figure 7 and Figure 8). 
Figure 7: What best encourages or enables communication with people of a different gender

- words used by men.

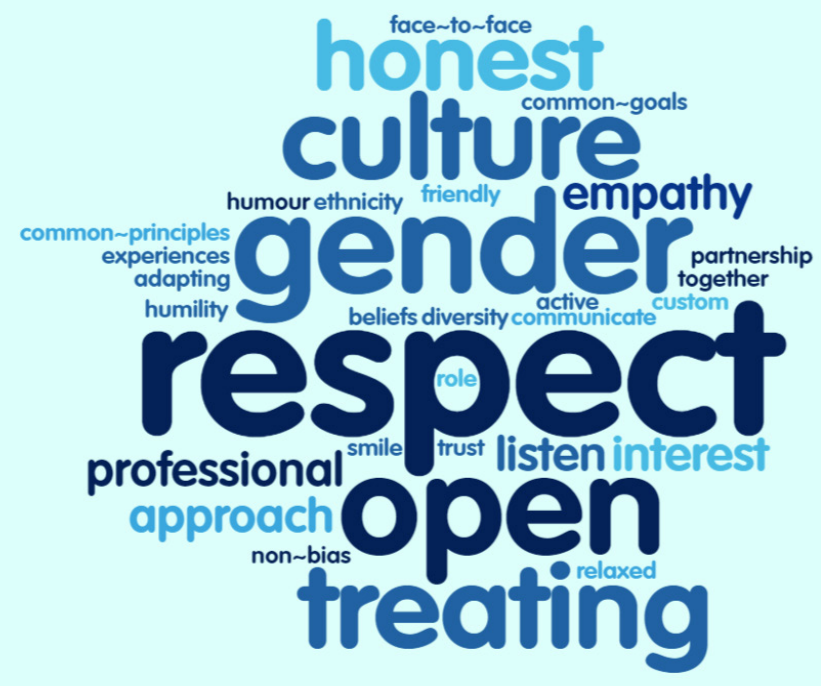

Figure 8: What best encourages or enables communication with people of a different gender

- words used by women

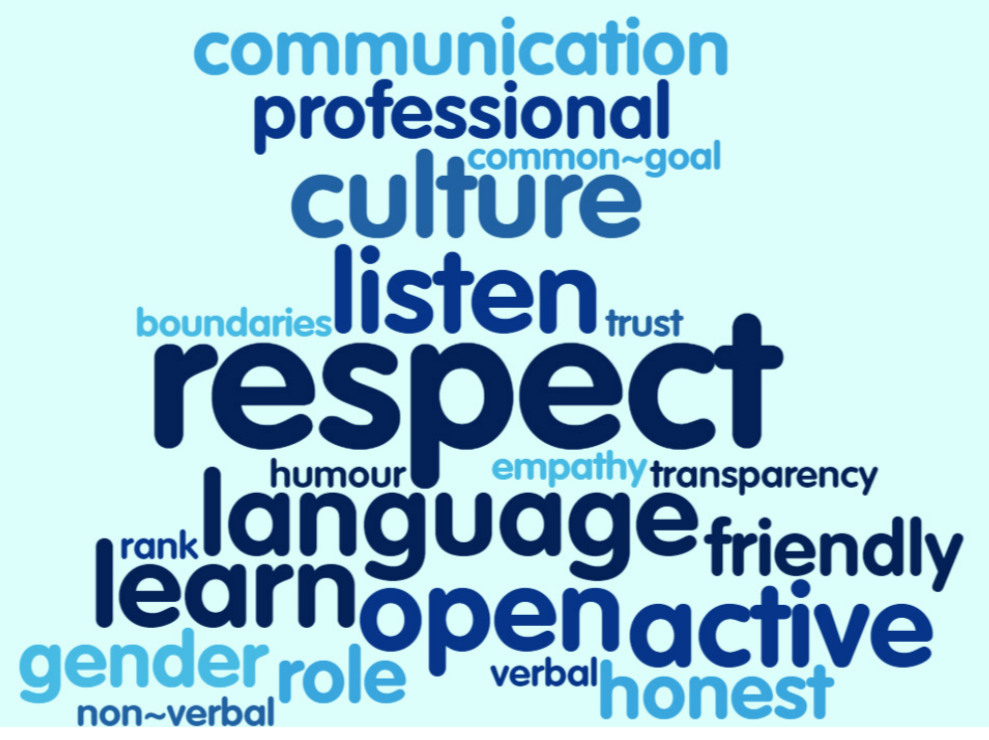


For men, what best enables communication with people of a different gender is being respectful, open, understanding, and culturally aware. Men are conscious of how they 'treated' people, referring to treating them as equals or with respect. Gender is the word referred to most often after respect. One man described his approach as "Actively seeking to include all genders in activities, discussions and roles, whilst adapting [my] approach to ensure their inclusion focuses on the skills, knowledge and ability that they contribute."

For ten men, communication with people of a different gender is enabled or encouraged through understanding cultural and gender norms. One man described this as "Cultural (including religious) understanding and the norms of gender interaction of the culture of the person" and another said it is having "Respect, knowledge of others culture and history including gender norms."

Two men said the enabler is having access to people of a different gender, for example "Diversity of gender through the ranks of police - access to different genders." Two men said that there is no relationship between gender and communication with one saying "Nothing. I don't change how I communicate based on gender" and another saying "Gender was irrelevant; communication is communication."

For women, what best enables communication with people of a different gender is being respectful, open, and culturally aware, actively listening and trying to learn the language. Two women felt their rank or their role in police is important in communication, with one woman saying her rank and role enables communication. It is unknown what her rank and role is. (A male respondent responded similarly saying "Having the same interests and roles in police" enables communication). The other female felt that men are not supportive of her role in police, explaining there is nothing that she is aware of that would break down the barriers of communication and adding "Men hate women being in the role I am in."

These findings suggest that police would benefit from a communication strategy that enables them to break through cultural barriers and organisational barriers, such as rank and roles, to access and communicate with people of a different gender.

\section{Deterrents to communicating with different gender}

This part of the survey informs of barriers to communication with people of a different gender. Survey participants were asked "Thinking about your international policing experience, what is most likely to hinder or deter you from communicating with people of a different gender to you." Participants could self-select from any of the answers provided and there was an opportunity to identify any other reasons and to make a comment. The choices for selection were: Language barrier; Being accused of sexual misconduct or misconduct generally; Breaching a cultural practice or causing offence; 
Concern for my physical safety; Avoiding gossip; Shy; Protecting my personal reputation; Protecting police reputation. Additional comments were made by 13 males. No women commented.

The main barriers for men communicating with people of a different gender are language barriers, which was selected by 49 males $(70 \%)$ followed by concern for breaching a cultural practice or causing offence ( 34 males or $48.57 \%$ ). Of the women, $11(68.75 \%)$ said breaching a cultural practice or causing offence, would deter them from communicating with people of a different gender. Six women $(37.50 \%)$ said language is a barrier for them.

Figure 9: Male and female responses to the question "Thinking about your international policing experience, what is most likely to hinder or deter you from communicating with people of a different gender to you. Select any that apply."

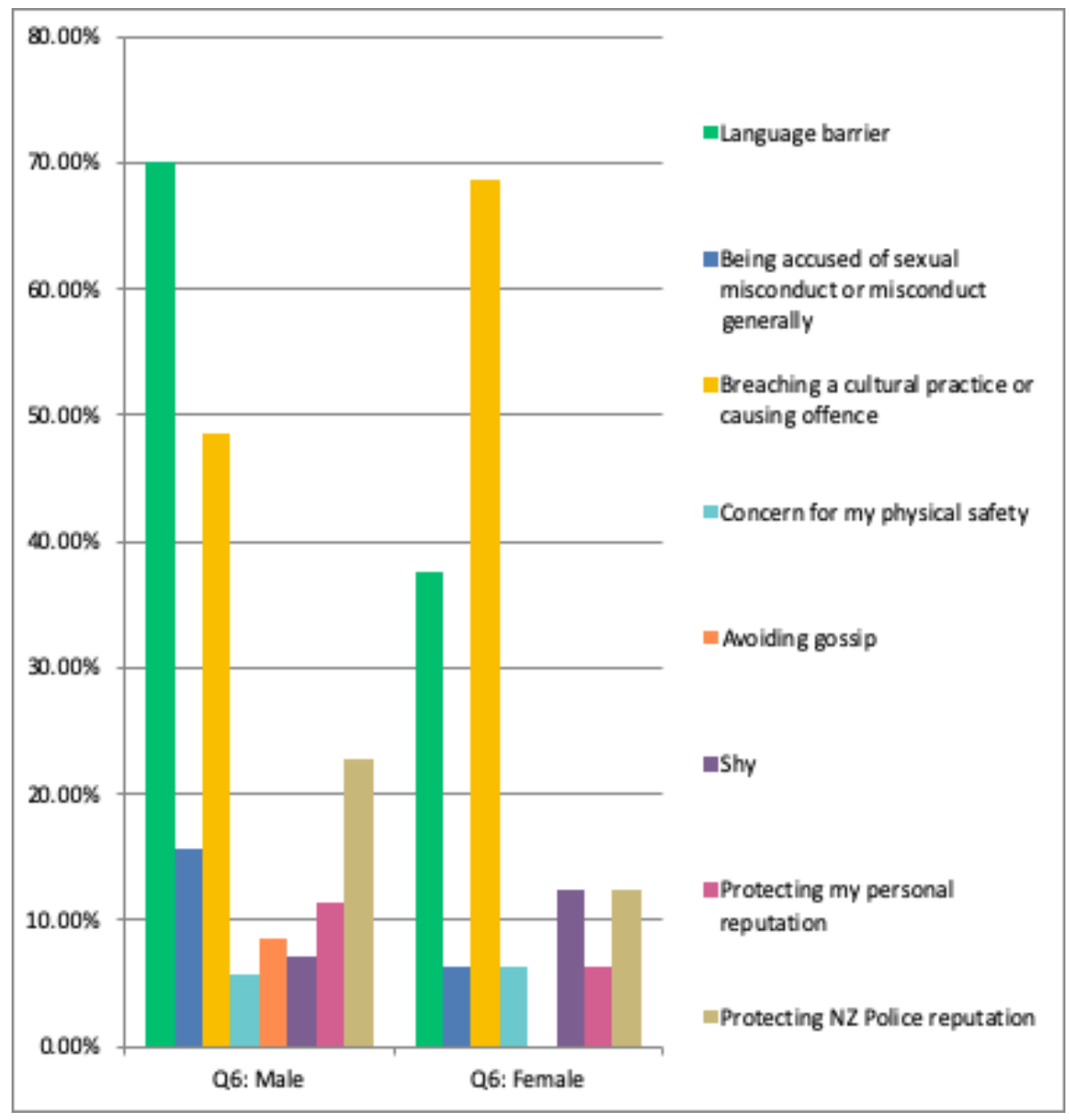


The data was then considered in relation to whether the person was a constable or non-constabulary. Most of the constabulary staff $(62.34 \%)$ and non-constabulary staff $(77.78 \%)$ identify language barriers as the main issue preventing communication with people of a different gender. Breaching a cultural barrier or causing offence is a similar barrier for constables (51.95\%) and non-constabulary staff (55.56\%). However, only constables (15.58\%) identify that being accused of sexual misconduct or misconduct generally is a communication barrier and that this is likely to hinder or deter them from communicating with people of a different gender. Additionally, more constables (22.08\%), compared to non-constabulary staff (11.11\%), are concerned about protecting the NZ Police reputation and said this is a barrier to communicating with people of a different gender. The constables' concerns may be an outcome of the Bazley report on police conduct which resulted in ten years of Government monitoring of police performance to develop an ethical workforce with standards, policies and guidelines to prevent inappropriate or unprofessional sexual behaviour. ${ }^{24}$ By not talking to people of a different gender for fear of sexual or other misconduct allegations, the constable potentially keeps their personal reputation and the reputation of police, safe.

Figure 10: Constabulary and non-constabulary responses to the question "Thinking about your international policing experience, what is most likely to hinder or deter you from communicating with people of a different gender to you. Select any that apply."

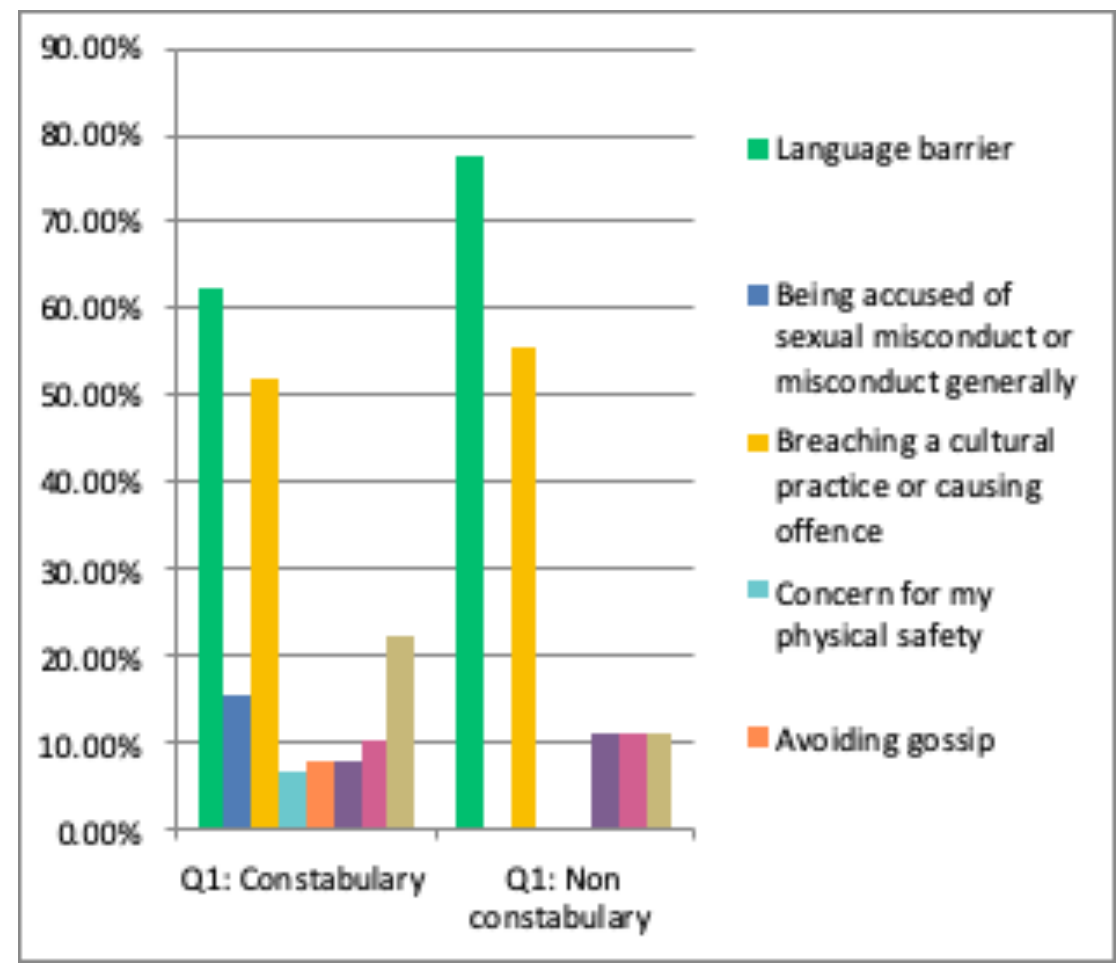


Survey participants were invited to consider what they thought would hinder other members of the police communicating with people of a different gender. Sixty-four males and 15 females commented. Language and cultural/religious barriers topped the list for both genders with 42 males and nine females believing that these are the biggest inhibitors. Six males and one female did not think there would be a common reason that would hinder police communication with someone of a different gender, variously responding "none", "unknown", "I don't think there is anything to hinder" and "I can't think of any." Other barriers to communication suggested by males are shyness, lack of confidence, indifference, and concern that actions would be misinterpreted or offend. Other barriers suggested by females are a gender imbalance, unconscious bias, avoiding gossip, arrogance, uncertainty and lack of understanding. Two females provided examples about how they are treated by others due to their gender with one female constable saying "I get ignored, because I am a female so I don't bother talking to other people." Another female constable said "Because of the lack of respect for women, some (not all) Police would rather speak to a male. In a physical training role, males were far more respected and listened to than a female instructor who had to first earn respect before being listened to."

Table 7: NZ Police responses to the question "Thinking about your international policing experience, what is most likely to hinder or deter you from communicating with people of a different gender to you?

\begin{tabular}{|l|r|r|r|r|}
\hline Selection & \multicolumn{1}{|c|}{ Male } & Female & Constabulary & Non-constabulary \\
\hline Language barrier & $70.00 \%$ & $37.50 \%$ & $62.34 \%$ & $77.78 \%$ \\
\hline $\begin{array}{l}\text { Being accused of sexual misconduct } \\
\text { or misconduct generally }\end{array}$ & $15.71 \%$ & $6.25 \%$ & $15.58 \%$ & $0 \%$ \\
\hline $\begin{array}{l}\text { Breaching a cultural practice or } \\
\text { causing offence }\end{array}$ & $48.57 \%$ & $68.75 \%$ & $51.95 \%$ & $55.56 \%$ \\
\hline Concern for my physical safety & $5.71 \%$ & $6.25 \%$ & $6.49 \%$ & $0 \%$ \\
\hline Avoiding gossip & $8.5 \%$ & $0 \%$ & $7.79 \%$ & $0 \%$ \\
\hline Shy & $7.14 \%$ & $12.50 \%$ & $7.79 \%$ & $11.11 \%$ \\
\hline Protecting my personal reputation & $11.43 \%$ & $6.25 \%$ & $10.39 \%$ & $11.11 \%$ \\
\hline Protecting police reputation & $22.86 \%$ & $12.50 \%$ & $22.08 \%$ & $11.11 \%$ \\
\hline
\end{tabular}

These findings suggest police may benefit from access to a gender advisor in the country to which they are deploying, as part of a communication strategy. Ideally this person would have an appreciation of the culture of the country in which the police are deploying. 


\section{Safety considerations when communicating}

This part of the survey considers whether issues of safety are preventing men and women from communicating with each other, potentially limiting opportunities for women's voice to be heard. Survey participants were asked to think about their most recent or current international policing experience and select how safe it is to meet a person of the same gender, or of a different gender, on their own in public or in private. Participants were asked to consider this in relation to meeting with indigenous/local people, expatriates, and people from partner agencies.

A total $75.41-96.73 \%$ of male respondents and 71.42-92.86 \% of female respondents reported good safety and great safety when meeting people across the three groups in public on their own regardless of gender. When meeting with indigenous/local people of the same gender on their own in public and in private, a higher percentage of females (85.71-92.86\%) reported good and greater levels of safety than males (80.00 - 88.52 $\%)$. Females felt safer meeting with indigenous females in public and in private, than meeting with females of expatriate or partner agencies in public or in private.

Females reported feeling less safe than males when meeting with people from expatriate and partner agencies of the same gender, in public, on their own. Females felt less safe than males meeting people from expatriate and partner agencies of a different gender in public on their own. When meeting with people from expatriate and partner agencies of a different gender, in private, on their own, females feel $20.12-24.05 \%$ less safe than males.

When meeting with indigenous/local people of a different gender in public, males $(75.41 \%)$ and females $(71.43 \%)$ reported similar levels of good and great safety. However, both males $(48.33 \%)$ and females $(50.00 \%)$ reported similar and significantly reduced levels of good and great safety when meeting on their own with indigenous/ local people of a different gender in private. There are similar reports from females, who said it was not safe $(35.71 \%)$ or small safety $(14.29 \%)$ and males who said it was not safe $(18.33 \%)$ or small safety $(28.33 \%)$.

Table 7: Percentage of males reporting good and great safety when meeting with people on their own

\begin{tabular}{|l|r|r|r|r|}
\hline People met with & $\begin{array}{c}\text { Same gender } \\
\text { in public }\end{array}$ & $\begin{array}{c}\text { Same gender } \\
\text { in private }\end{array}$ & $\begin{array}{c}\text { Different gender } \\
\text { in public }\end{array}$ & $\begin{array}{c}\text { Different gender } \\
\text { in private }\end{array}$ \\
\hline Indigenous/local & $88.52 \%$ & $80.00 \%$ & $75.41 \%$ & $48.33 \%$ \\
\hline Expatriates & $93.44 \%$ & $90.00 \%$ & $93.44 \%$ & $85.00 \%$ \\
\hline Partner agencies & $96.72 \%$ & $93.33 \%$ & $96.73 \%$ & $88.33 \%$ \\
\hline
\end{tabular}


Table 8: Percentage of females reporting good and great safety when meeting with people on their own

\begin{tabular}{|l|r|r|r|r|}
\hline People met with & $\begin{array}{c}\text { Same gender } \\
\text { in public }\end{array}$ & $\begin{array}{c}\text { Same gender } \\
\text { in private }\end{array}$ & $\begin{array}{c}\text { Different gender } \\
\text { in public }\end{array}$ & $\begin{array}{c}\text { Different gender } \\
\text { in private }\end{array}$ \\
\hline Indigenous/local & $92.86 \%$ & $85.71 \%$ & $71.43 \%$ & $50.00 \%$ \\
\hline Expatriates & $85.71 \%$ & $78.57 \%$ & $78.57 \%$ & $64.28 \%$ \\
\hline Partner agencies & $85.72 \%$ & $78.57 \%$ & $78.57 \%$ & $64.28 \%$ \\
\hline
\end{tabular}

When invited to comment on safety when meeting with a different gender in public, 45 males and 13 females (54 constables and five non-constabulary staff) provided a comment. Gossip, rumour and perceptions are raised as a concern by 17 constabulary staff. Three males and two females said they have no issues.

When invited to comment on safety when meeting with a different gender in private, 44 males and 13 females (51 constables and six non-constabulary staff) provided a comment. The constabulary staff provided a range of options they use to keep themselves safe and "risk manage" such situations. Suggestions from male constables were to include another person of the same gender in the meeting; to inform others of scheduled meetings in advance; to build trust to overcome local cultural issues; to record the meeting well; to gain expatriate and partner agency support and awareness; and to tell colleagues where they are going and with whom. Suggestions from female constables are to avoid meeting in private (unless appropriate) and to inform others of the meeting. Both male and female constabulary staff pointed out that it is a matter of using situational awareness. Five males and two females said that they had no issues.

This data informs us of situations where NZ Police personnel feel most safe communicating with men and women internationally and the safeguards police use to protect themselves in less safe situations, which is useful for developing tactical communication approaches. 
Figure 11: Male and female perceptions of safety when meeting indigenous/local people of same gender, on their own, in public

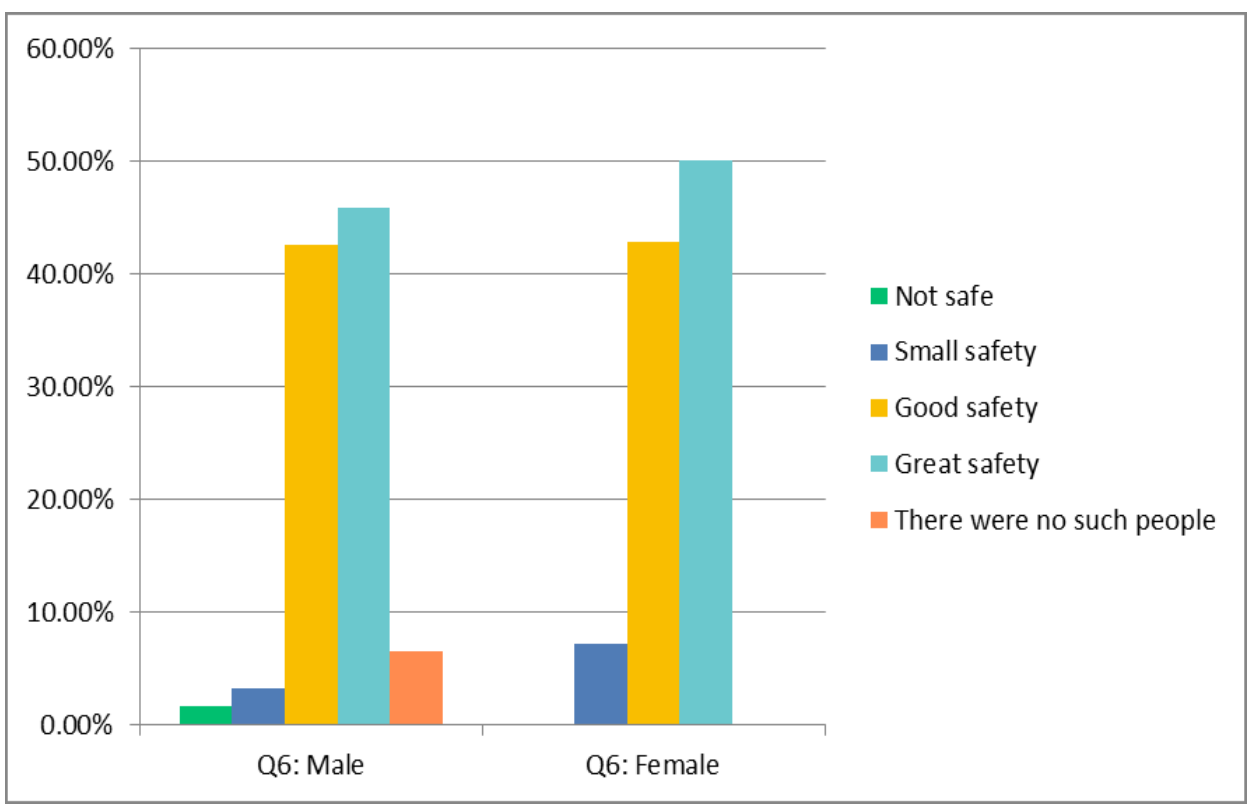

Figure 12: Male and female perceptions of safety when meeting indigenous/local people of different gender, on their own, in public

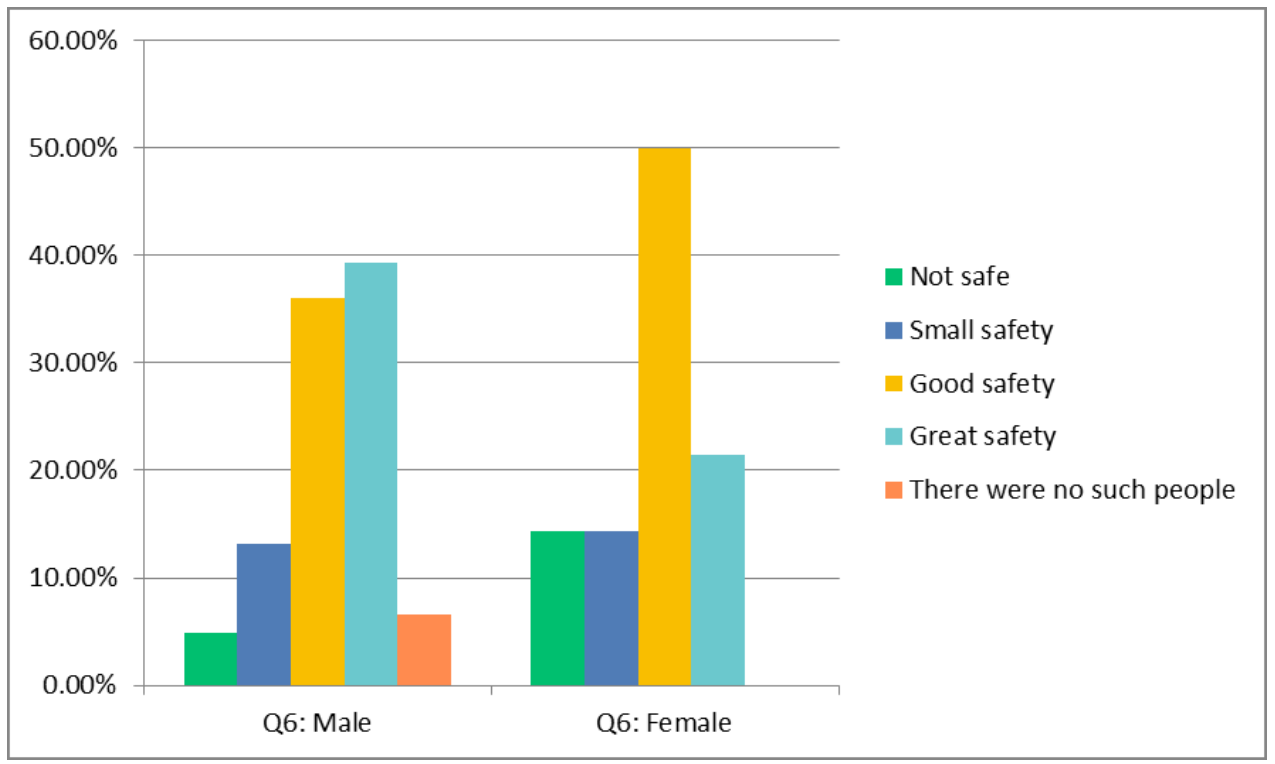


Figure 13: Male and female perceptions of safety when meeting indigenous/local people of same gender, on their own, in private

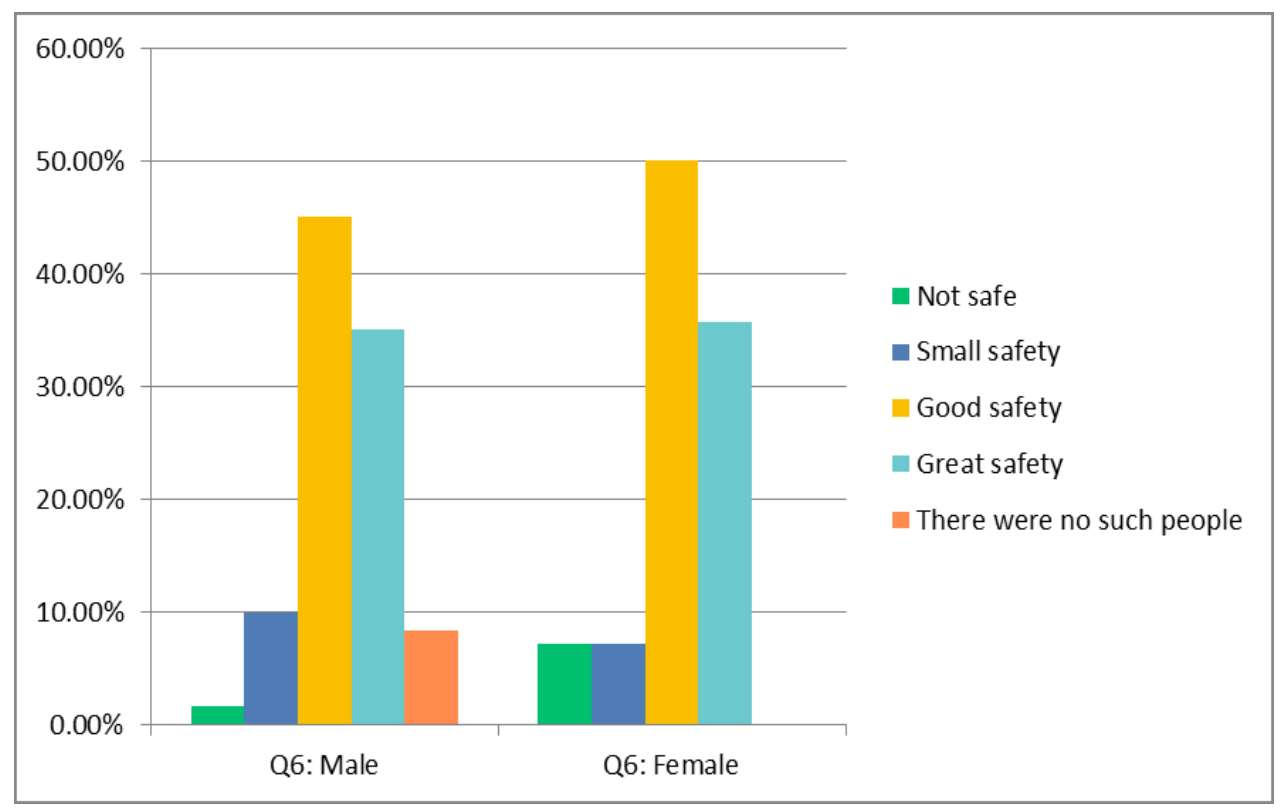

Figure 14: Male and female perceptions of safety when meeting indigenous/local people of different gender, on their own, in private

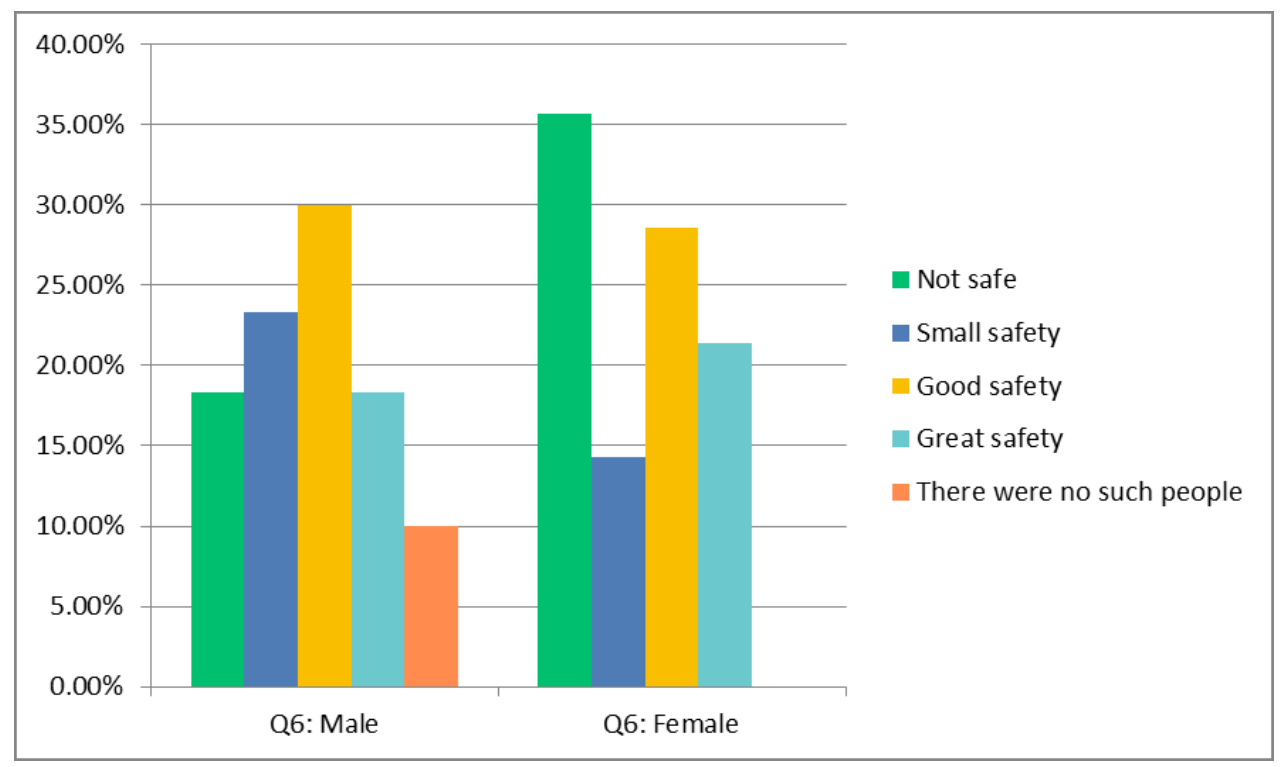




\section{Focus group findings}

Focus groups were held with the International Security Group (ISG) in NZ Police, who have responsibility for implementing the NZ National Action Plan on Women, Peace and Security. The first part of the focus group discussion establishes what the participants know of the plan and how it influences their work. The participants were asked how the plan is communicated and who the key players are. A further question was designed to identify impediments to delivering the plan, or pathways of greater or lesser resistance to delivering it, as these may identify areas for improved communication. The second part of the research establishes how imagery (visual representation) is used, or could be used, as a method of communicating the plan.

The women in ISG were well-informed of the NZ National Action Plan, listing 29 facts about it. They were aware that NZ Police is responsible for implementing 11 actions across the four pillars of prevention, protection, peace-building and relief and recovery and that MFAT report annually to Government on implementation. The women knew that aspects of the plan are to be incorporated throughout the ISG programme and this includes a broader approach of the ISG toward gender. The women described this as "putting the gender perspective" across the programme and being "gender supportive." In their view, this includes encouraging women to deploy internationally and increasing the number of women deploying in senior roles and leadership roles. It also means including women in decision making in the countries NZ Police are operating in. The women discussed actions in the plan, such as pre-deployment training about the plan, sharing lessons learned, sharing good practice internationally and advocating at international fora. They were concerned that the plan wasn't being properly implemented and integrated within Police. One woman explained it by saying "Make it a real part of business as usual, not just ticking the box."

The men's knowledge about the plan was mixed. One had good understanding, two said they knew "nil" about it and a third said he did not know a great deal, however, he is aware that it is important to NZ Police and that it increased acceptance of the work that women carried out in the organisation. Regardless, all the men were strongly aware that the ISG are reviewing their overseas deployment policies and identifying and overcoming barriers to women applying for roles, including leadership roles, overseas. The Pitcairn Island programme was provided as an example of a revised appointment policy to achieve a balance of gender on deployment. ${ }^{3}$

$3 \quad$ Previously the police officer had to be accompanied by their partner, husband or wife. The new appointment policy enables a constable and accompanying person to deploy. The accompanying person can be a friend or relation. This means that the applicant does not have to be in a relationship or, if the applicant is in a relationship, one of the partners can stay in New Zealand working, or to enable their children's schooling to remain uninterrupted. 


\section{The influence of $\mathbf{1 3 2 5}$ - finding pathways to enhance communication}

Participants in the focus groups were asked how the NZ National Action Plan influences the work of the ISG. The women felt that implementation is in a transition stage "moving from working out what it means to 'doing"' There was a general feeling that as implementation progresses, knowledge and understanding will increase. For some, this means their role is "influencing fellow managers and senior managers to take this seriously" and "enabling people to understand what it means from a practice perspective." The women wanted to include a gender perspective in the planning of all development programmes "as a matter of course, rather than after-thought." Communication is an integral part of this process and ranges from "reminding and advocating for incorporation at all levels and increasing plans visibility at higher levels with the executive" to "promoting the importance of the gender perspectives of the National Action Plan amongst my colleagues and staff, especially [when] arranging tasks during staff meetings." This work includes evaluating what the ISG is delivering about the National Action Plan in pre-deployment training and refining it.

The women wanted increased dialogue regarding gender in all programme design and specific gender targets in results measurement frameworks. Monitoring and evaluation is recognised as an essential part of implementation however questions remained on how success can be achieved and communicated. A female in the ISG described the coaching and mentoring style required to implement the plan as "A process of building confidence, skills and knowledge brick by brick, layer upon layer."

The men said the National Action Plan influenced their work through the appointment and selection process. They were reviewing the overseas deployment policies and striving to identify and overcome barriers to women applying for roles, particularly leadership roles, overseas. The recruitment and selection processes for international roles had changed, and one man said he was "insisting on an even balance of gender on deployment."

The men felt the way to communicate the plan is through the advertising of vacancies, recruiting the right people, and through pre-deployment training. However, there was uncertainty on how the plan translates to actions operationally, with one man acknowledging "First learn more about it, then discuss with workmates and peers." They wanted the plan communicated "in a manner that is understood easily by all staff." For the men, the focus is learning more about the National Action Plan and briefing staff and the Police Executive about it. Key personnel through whom the plan could be communicated by police were identified and included team leaders of police deployed overseas, programme officers who co-ordinate the overseas programmes and police managers. 


\section{Resistance and impediments to implementing 1325}

The women's perspective

This part of the research is to identify the barriers, resistance and impediments to implementing 1325 , which could potentially be turned into opportunities for enhanced communication strategies. When asked where the resistance is and what the impediments are, the women talked about a lack of leadership at the highest levels. The women felt that high level engagement from the lead agency MFAT was lacking and that the police executive and the Police Minister could do more to advocate for the plan. They felt the backing of police management is needed to get constant movement on the National Action Plan, reasoning that if NZ Police demonstrate their commitment to the plan, then the ISG will be in a better position to demonstrate its effectiveness in countries where they work by "walking the talk." Men are seen as having an important role as "males can sometimes be the strongest leaders and champions for gender progress."

The women cited other impediments as "ingrained attitudes, taking time to change", "lack of desire", "apathy", "people not believing in it" and "lack of knowledge about the existence of the plan." Where the plan is known, it was being "marginalised for "more important things"' and treated as a "tick the box exercise." Instead of being valued, it was seen by some police as a "nice to have." Sometimes it could be a "switch off" topic. It was felt that immediate gains could be achieved with "management buy-in at all levels and champions to drive it forward." Management could make it a core requirement, business as usual, and change the mind-set of staff from "another thing they have to do."

Women felt progress is being "limited by tradition and cultural aspects both in NZ Police and especially in Pacific Islands." The traditional views of male and female roles were seen as being "promoted by both men and women." The women are conscious that police need to role model good practice internationally and to start by doing this in the NZ Police workplace. Two areas of communication in the workplace were given as examples that police could improve. This is the language used to describe women (which women said continued even when perpetrators had been asked to stop) and for people to stop making negative comments about women. One woman noted that female managers appeared to be judged more critically about their performance than men. One woman explained it as internal bias saying "We need to acknowledge the fact that some persons, both internally within NZ Police and externally, within the communities we work with, may have opinions or internal bias which may be based on a number of factors (including but not limited to their upbringing and religion) which lead them to feel or behave in a way which is contra to what we are trying to achieve.... If we are trying to encourage more female participation/representation at a senior level 
with the host countries or at particular events/activities or changing a cultural norm, there may be push back from our counterparts or communities. Possibly even from the women themselves."

The women did not see the international obstacles as insurmountable, saying that police can influence a gender perspective across the whole aid programme design and planning process. One suggestion was to include gender clauses in partnership arrangements with other countries. Another suggestion was improved pre-deployment training which addressed gender issues. Gender focussed monitoring and evaluation systems was also suggested. One woman described the communication challenges of enabling women's voice to be heard by saying "We can change our behaviour by role modelling overseas and having more women at the table, but the issue will be actually by getting partner police agencies to bring females to the table."

\section{The men's perspective}

Men were not able to contribute much to this conversation, having previously admitted to knowing very little about the NZ National Action Plan. However, they were aware of barriers and described these as resistance to change and new ideas. "There will always be those who don't agree, or see women in the roles they were in thirty years ago," said one man. The men wanted good examples to explain what was required or to be achieved in messages communicating the plan.

\section{Communicating Women, Peace and Security with imagery}

The ISG wanted to rebrand the police image of international policing, describing their current imagery as not reflective of their work. An analysis of the ISG pages on the New Zealand Police internet site found that the leading page has no images and other pages have eight tiny images, of which one is a repeat..$^{25}$ Some of the images were so small that it is unclear whether the people in them are male or female. None of the images had captions to interpret them, making it difficult to understand their context. Three images show NZ Police constables holding children and in 2021, the 'Current ISG Deployment' page remains not updated since $2013 .{ }^{26}$

The ISG were invited to bring images to the focus group that depicted to them international policing at its best. The invitation did not make any reference to gender, as the intention was to see what images were favoured. Most participants said they had difficulty finding images as there was no single source database of suitable images to access. Three women and one man hand-drew their images. One woman sourced her images from a female colleague, who she knew is proactive at taking photographs that are suitable to use. Another woman was concerned about bringing images that

$4 \quad$ The ISG said that 'Knowledge, attitudes and practices' surveys are one method they use to better understand their international workplace. 
she did not have permission to publish. The men accessed images from their personal collections. The staff said there was no policy or practice documentation about using images to publicise and promote the work of ISG. This means that police have no ethical protocols for taking photographs of policing in the international workplace to communicate their work.

When asked what messages there are about gender in their imagery, the men said their images showed positive messages, of NZ Police sharing, working well together, and a team approach. They said the fact there were no women from NZ Police in most of the images they selected, is because their presence was not in the country at that particular time, although they had been present in the past or were appointed for upcoming roles. They felt their imagery demonstrated that all police personnel have a contribution to make toward New Zealand and regional security.

In contrast to the men, when the women talked about their imagery and their international policing experiences, they expressed concern about police leadership. "Operating overseas can be difficult because of lack of traction!" one woman said. "We are there but the positive impact is negligible." "Leadership is primarily a male thing in the Pacific. If there were more women in leadership, things would be better," said another woman. One of the women expressed concern that the only female leaders seated at the table in discussions, were the NZ Police representatives. Without access to women leaders, the women from NZ Police felt they could not do their job effectively. "Women bring a different perspective. If you provide assistance to women, they will make sure the family benefits from it as well. This may not happen if the male receives the assistance," one woman explained.

These findings suggest that the role of a gender advisor, for example, working with the Pacific Islands Chiefs of Police, would benefit in developing a communication strategy with imagery to support the work of MFAT, NZ Police and the local police.

\section{Selecting the right images for the right message}

The women provided 23 suggestions on how images could be used to communicate the NZ National Action Plan. The women want images that depicted strong women, women conducting a briefing, women directing work, women taking the lead and images that presented "the reality of what women do."

They want more images of women in the Pacific seated at the table participating in decision making with men, women doing police work, women in leadership roles and women as role models. They recommend that images are selected with care, are gender inclusive and normalise equal gender participation. They want images that depict the work of their international police development programmes and the direction NZ Police want to move toward, such as developing more female leaders with partner coun- 
tries. It was felt the images should demonstrate the different activities NZ Police deliver to host-country police and communities, such as mentoring, peacekeeping and disaster response. They want to show NZ Police in all types of mission roles across the spectrum of leadership, training and operational policing. It was felt images such as these should demonstrate the different ways policing could be delivered, using or applying a gender perspective and gender representation.

The women feel that men, including men in NZ Police, could be more supportive of women in leadership. The women want images that move away from traditional gender roles, and to include images that depict men in non-traditional roles. They want careful messaging where women are "not always depicted as the carer and not with children all the time."

The males provided ten suggestions to use images for communicating the NZ National Action Plan. Men want strong and powerful images that change NZ Police perceptions of New Zealand's role in international policing. For them, it is important to use images that show where NZ Police deploy internationally, and images for recruiting the right personnel into the ISG and into international policing. They want images that encourage police personnel to see international policing as a development opportunity and of value to the development of their professional career in policing. To illustrate this, they referred to a photograph of a Maori female police officer, holding an infant in her arms whilst serving overseas, which they believed to be an iconic image of women in policing. When asked if this was a good image of women in policing, the men responded as one, that it is. One man said the role of women and children is really important in the Pacific, where much of their international policing contribution is made. In his view, children brought the parents along, and through children, police are able to break down barriers and meet and communicate with parents. This type of imagery bore no relation to how their female colleagues wanted women in policing depicted, suggesting there is value in consulting a gender advisor to develop a communication strategy using imagery.

\section{What messages would imagery communicate about police?}

When NZ Police deploy to another country, what message do they want to convey in imagery? Women said the imagery should indicate that police are a guest of their international partners, and don't operate on their own. The imagery would represent NZ Police "at the table" as a trusted partner. The imagery would be representative of NZ Police demographics and of the host country demographics. It would show different perspectives of policing, involve women in leadership roles, and be in the local environment, or demonstrate a local context.

Similarly, the men value images that demonstrate NZ Police as inclusive with the ability to relate and work with all. These include images that value diversity and gender, and 
demonstrate sharing, comradeship, looking after each other and acceptance. Men value images that communicate the global focus of the work of NZ Police, and the limitless boundaries of where NZ Police might be asked to provide an international service. It was important to men that the message of the imagery helps people to understand that the NZ National Action Plan is outward looking and globally focussed as it contributes to regional security, which in turn contributes to keeping New Zealand a secure environment. The inference from the men is that women's contribution to peace and security in the Pacific contributes to regional security and New Zealand's security.

\section{Summary and Conclusion}

This study has examined the communication approaches of NZ Police to operationalise the NZ National Action Plan for Resolution 1325, Women, Peace and Security. In the quantitative data, police personnel identified the importance of presenting a professional image of themselves when communicating with people, including people of a different gender to their own. The qualitative and quantitative data in this research identified language and culture as major barriers for men and women in NZ Police wanting to communicate with people of a different gender internationally.

By using imagery which normalises communication between men and women, these barriers may be overcome. Normalisation through imagery enables leaders at the parliamentary level and the executive level of security sector agencies, to be visible in demonstrating their professional commitment to women in leadership and engaging women in decision making conversations. Further, imagery gives status to police leaders, by demonstrating their commitment to listening to the voice of women politicians and women community leaders. By normalising and making visible communication between men and women at the highest levels, operational staff are empowered to 'walk to talk' with people of a different gender, at their own levels of influence.

This research validates that an effective communication strategy ensures gender equality in the representation of men and women in policing communicating with men and women on matters relating to peace and security. The findings stress the need for the development of policy that embeds imagery-based communication as a strategic objective both at inter-organisation and intra-organisational levels. This embedding strategy provides a context for the use of monitoring and evaluation systems and ensures managers that discussions between genders are taking place that reflect the intent of resolution 1325 toward peace and security outcomes.

In summary, developing policies and practices based on communication strategies materialises the willingness and desire of the men and women in policing to deliver to the intent of the NZ National Action Plan. This research contributes to the design and development of communication strategies that enable key messages to be directed to specific audiences in a cultural context. By combining the knowledge, skill and expe- 
riences of men and women, with strong communication and visible leadership, men and women in policing will be better positioned to achieve their Women, Peace and Security objectives and outcomes.

1 United Nations Security Council. United National Security Council Resolution 1325 (2000). 31
October 2000. Available from https://undocs.org/en/S/RES/1325(2000).
2 Ibid.
3 "NATO Secretary General's report on implementing United Nations Security Council Resolution
1325 on women, peace and security, and related resolutions" 17 November 2011. Available at http://
www.nato.int/cps/en/natolive/official_texts_81007.htm; United Nations, Ten-year Impact Study on
Implementation of UN Security Council Resolution 1325.(2000) on Women, Peace and Security in
Peacekeeping. 2010. Available at https://www.globalpolicy.org/images/pdfs/10year_impact_study_1325.
pdf; "Conference on Women and War: Power and Protection Session," 4 November 2010. Available at
https://2009-2017.state.gov/s/gwi/rls/rem/2010/151653.htm 4 "Security Council, Unanimously Adopting Resolution 1325 (2000) Calls For Broad Participation Of Women In Peace-Building, Post-Conflict Reconstruction,” 31 October 2000. Available at https://www. un.org/press/en/2000/20001031.sc6942.doc.html

5 "National implementation of Security Council resolution 1325 (2000)." Inter-Agency Network on Women and Gender Equality. United Nations. Available from https://www.un.org/womenwatch/ianwge/ taskforces/wps/national_level_impl.html

6 "National Action Plans for the Implementation of UNSCR 1325 on Women, Peace and Security," Peacewomen. Available at https://www.peacewomen.org/member-states

7 "New Zealand National Action Plan for the implementation of United Nations Security Council Resolutions, including 1325, on Women, Peace \& Security 2015 - 2019.” October 2015. Available at https:// www.police.govt.nz/about-us/publication/new-zealand-national-action-plan-implementation-united-nations-security-council; "Release of New Zealand's National Action Plan on Women, Peace and Security," 14 October 2015. NZ Police. Available at http://www.police.govt.nz/news/release/release-new-zealand$\% \mathrm{E} 2 \% 80 \% 99$ s-national-action-plan-women-peace-and-security

8 "New Zealand National Action Plan for the implementation of United Nations Security Council Resolutions, including 1325, on Women, Peace \& Security 2015 - 2019." October 2015: 23, 24. Available at https://www.police.govt.nz/about-us/publication/new-zealand-national-action-plan-implementation-united-nations-security-council

9 UN Women, "Asia-Pacific Regional Symposium National Action Plans on Women, Peace and Security," 2016: 13. Available at https://asiapacific.unwomen.org/en/digital-library/publications/2016/12/ nap-report\#view

10 Cynthia Weber, "Popular visual language as global communication: the remediation of United Airlines Flight 93," Review of International Studies 34, Special Issue S1: Cultures and Politics of Global Communication (2008): 137-153. DOI:10.1017/S0260210508007833.

11 Cynthia Enloe, "How Can you Tell If You're Becoming Militarized? Doing a Feminist Audit," 6 October 2016. YouTube video, 6:20, https://www.youtube.com/watch?v=yTuSCKVwGlA

12 Vandra Harris and Andrew Goldsmith, "Gendering Transnational Policing: Experiences of Australian Women in International Policing Operations," International Peacekeeping 17, no. 2 (2010): 301. DOI:10.1080/13533311003625167.

13 David Capie, "Peacekeeping - New Zealand's involvement in peacekeeping," Te Ara, updated 10 June 2015. Available at https://www.teara.govt.nz/en/peacekeeping/page-1; "Past ISG deployments," New Zealand Police. Available at http://www.police.govt.nz/about-us/programmes-initiatives/isg/past-deployments

14 "New Zealand National Action Plan for the implementation of United Nations Security Council Resolutions, including 1325, on Women, Peace \& Security 2015 - 2019." October 2015. New Zealand Police. Available at https://www.police.govt.nz/about-us/publication/new-zealand-national-action-plan-implementation-united-nations-security-council 
15 Ibid; "Collaboration strengthens Pacific detector dog capability," 3 September 2015. New Zealand Police. Available at http://www.police.govt.nz/news/release/collaboration-strengthens-pacific-detector-dog-capability

16 "Evaluation Reports 2016," Ministry for Foreign Affairs and Trade. Available at https://www.mfat. govt.nz/en/aid-and-development/our-approach-to-aid/evaluation-and-research/evaluation-reports-2016/; "Isolated island calls Kaikohe cop," Northern News, 31 January 2009. Available at http://www.stuff. co.nz/auckland/local-news/northland/northern-news/330538/Isolated-island-calls-Kaikohe-cop

17 "McCully to Beijing and Guangzhou," Beehive, 30 April 2015. Available at https://www.beehive. govt.nz/release/mccully-beijing-and-guangzhou; "Interpol." New Zealand Police. Available at http:// www.police.govt.nz/about-us/structure/teams-units/interpol

18 New Zealand Government. New Zealand Police Annual Report 2014/2015. Available at https:// www.police.govt.nz/sites/default/files/publications/annual-report-2015.pdf; New Zealand Government, New Zealand Police Annual Report 2015/2016. Available at http://www.police.govt.nz/sites/default/files/ publications/plc448_ann_rep_web.pdf

19 "Diplomatic Protection Service." Available at https://www.police.govt.nz/about-us/structure/policeteams-and-units/diplomatic-protection-service; Matthew Tso, "New Zealand Police anti-terrorist unit costs taxpayers $\$ 6.2$ million." Stuff, December 23, 2018. Available at https://www.stuff.co.nz/national/ crime/109460758/new-zealand-police-antiterrorist-unit-costs-taxpayers-62-million; "International Service Group (ISG)." Available at https://www.police.govt.nz/about-us/programmes-initiatives/isg

20 "Concepts and definitions," UN Women. Available at https://www.un.org/womenwatch/osagi/conceptsandefinitions.htm

21 New Zealand Government, New Zealand Police Annual Report 2015/2016. Available at http://www. police.govt.nz/sites/default/files/publications/plc448_ann_rep_web.pdf

22 New Zealand Government, Convention on the Elimination of All Forms of Discrimination against Women Eighth Periodic Report by the Government of New Zealand March 2012 - March 2016. Available at https://women.govt.nz/sites/public_files/CEDAW\%20Report\%202016_WEB.pdf

23 Ibid.

24 Commission of Inquiry into Police Conduct, Report of the Commission of Inquiry into Police Conduct Volume 1, 2007. Available at https://www.parliament.nz/resource/0000055162; New Zealand Police, A decade of change 2007-2017; Implementing the recommendations from the Commission of Inquiry into Police Conduct, 2017. Available at https://www.police.govt.nz/sites/default/files/publications/ plc455-strategy-document.pdf

25 "Current ISG deployments," New Zealand Police. Available at https://www.police.govt.nz/about-us/ programmes-and-initiatives/international-service-group-isg/current-isg-deployments; "ISG Introduction," New Zealand Police. Available at http://www.police.govt.nz/about-us/programmes-initiatives/ isg/introduction; "Past ISG deployments," New Zealand Police. Available at http://www.police.govt.nz/ about-us/programmes-initiatives/isg/past-deployments

26 “Current ISG deployments," New Zealand Police. Available at http://www.police.govt.nz/about-us/ programmes-initiatives/isg/current-deployments 